\title{
Employee Performance and Retention: A Comparative Analysis of Theory X, Y and Maslow's Theory
}

\author{
Khizar Hayat Khan Tahir * Khalid M. Iraqi ${ }^{\dagger}$
}

\begin{abstract}
This study aims at examining the relationship amongst motivation theories applied by universities on employee retention and their performance. It is an interesting insight in the current era in terms of realizing that motivation theories still have their impact on management practices. Retaining employees and managing their performance to the best level has always remained a dream for managers. The methodology adopted is quantitative using a closed ended questionnaire which helped in response generation from 219 teaching and non-teaching university employees. Results revealed that managers who used theory X approach to manage employee retention and performance had weaker outcomes than the ones using theory $Y$ and Maslow's hierarchy of needs theory. The results are beneficial for university management in terms of motivating employees as majority of employees are well qualified and tend to rise using their own skills and capabilities rather than guiding themselves using strict compliance.
\end{abstract}

Keywords: Theory X, Y, Motivation, Maslow's hierarchy of needs, university employees

\section{Introduction}

The organizations are confronted with several challenges in which employee retention and performance are the important ones. In Pakistan the private universities are confronted with issues such as high turnover and diminishing performance over a period of time. The pay structures and the management practices are found to be the identified causes identified (Kim, 2016; Anitha, 2014). The organizations that take care of the employees remain stable over a period of time and hold the strength to develop competitive edge in the marketplace (Pang \& Lu, 2018). The employees retained in the workplaces are predictors of success at individual and organizational levels (Matongolo, Kasekende, \& Mafabi, 2018).

The ever changing environment demands (Fatehi, Veliyath, \& Derakhshan, 2008) that the universities develop programs that are market oriented and have the capability to attract students and act, as clients to fulfill their job related requirements; thus, providing them the competitive edge over others (Parakhina, Godina, Boris, \& Ushvitsky, 2017). To fulfill these requirements, the universities need to have a pool of employees that can be relied upon and this can be achieved by motivating the talented employees. It has been found that HR policy like fair performance review, job contentment, employee apprecia-

\footnotetext{
*PhD Student, Department of Public Administration, University of Karachi, Pakistan E-mail: khizarjatoee@gmail.com

†Supervisor, Department of Public Administration, University of Karachi, Pakistan.
} 
tion, empowerment and remuneration act as catalyst to determine employees' motivation (Umer, Khalil, \& Shirwani, 2016). The management practices to motivate employees have their worth in contributing towards the job satisfaction and organizational commitment of employees. If the degree of job satisfaction is high then there are chances to retain employee for longer and vice versa. Similar connection has been observed with the performance of the employees as an outcome (Chen, Zhao, Liu, \& Dash Wu, 2012). It is commonly observed that the employees generally leave their bosses; not their organizations. This is the fact which identifies the underlying truth that the practices adopted for motivating employees are important.

The practices adopted at the organizational level to manage the work outcomes of employees differ from sector to sector. Several studies have examined the issues of employee turnover and decreased performance in the Pakistani context but somehow the context of theory X, theory Y and Maslow's hierarchy has not been focused. It has been recently noted that motivation of employees leads to job satisfaction and thus enhances organizational performance as a whole (Pang \& Lu, 2018).

The main purpose of this study is to examine the factors that have an influence on employee retention and their performance in the context of private sector universities. The three approaches were used to examine the influence which the theory $X$ approach, theory $\mathrm{Y}$ approach and Maslow's hierarchy of needs approach used by the university management. These are the motivational approaches used for decreasing turnover and performance issues. The study provides an insight to the management practitioners in identifying the approach that is most useful in retaining the employees working in the private sector universities and performance of employees is further supported by the retention of valuable employees.

The major objectives of the study include; to examine the relationship of theory $X$, theory $Y$ and Maslow's hierarchy on employee retention and to examine the relationship of theory X, Y and Maslow's hierarchy on employee's performance.

\section{Literature Review}

The literature review is divided into two subsections representing a connection between the constructs of the study.

\section{Employee Motivation (Theory X, Theory Y and Maslow's Hierarchy) and Retention}

Employee retention is seen as encouraging employees to remain in the organization for continued operations of the organization and ultimate achievement of the set goals. Das and Baruah (2013) regarded human resources as life blood for any organization and have laid importance to maintain and sustain a healthy pool of human resources for continued operations. Retaining employees is necessary to meet the competitive requirements of the market. The question arises how to retain the human resources for sustained operations. This question is true for all types of organizations whether operating in services sector or 
manufacturing sector (Dartey-Baah \& Ampofo, 2016). The need becomes more evident where the services are to be provided to the customer that is the case of service sector organizations especially the educational institutions.

The approaches and styles adopted by the leaders in the organizations have concrete impact on these employees' related outcomes especially the philosophies adopted and the theories practiced. The managers not taking care of employees are at loss in the longer run and vice versa (Gyensare, Anku-Tsede, Sanda, \& Okpoti, 2016). Various perspectives prevail in research regarding resentencing employees. The researchers are of the view that the organizations have developed a sense to retain valuable employees and consider them as strategic assets (Rao, 2017). At the same time the organizations looking for employer branding also need to have a pool of talented employees (Matongolo et al., 2018; Dechawatanapaisal, 2018) but at the same time the studies reporting the turnover of employees are also in abundance (Alferaih, Sarwar, \& Eid, 2018; Madariaga, Oller, \& Martori, 2018). Similarly the experts have agreed to the fact that organization's inability to adopt practices emphasizing employee retention is becoming an everlasting challenge.

This depends upon the practices adopted by the leaders to maintain and sustain well develop pool of employees. In this run it becomes a foremost responsibility of the leaders to develop and adjust the strategies meeting the enhanced volatility and turbulence prevailing in the continuously changing competitive environments (Arslan \& Staub, 2013) like educational institutions. For addressing the volatility and turbulence the leaders are found using various approaches including the application of theory $\mathrm{X}$, theory $\mathrm{Y}$ and Maslow's hierarchy approaches to address the employee turnover and retention issues (Ng'ethe, Namusonge, \& Iravo, 2012; Gwavuya, 2011). Gürbüz, Şahin, and Köksal (2014) examined influence of theory $X$ and theory $Y$ on the employees' attitudes and behaviors in military settings and found that theory $Y$ perspective possessed by the leaders reaped positive and significant results as compared to theory $X$.

Theory $X$ and Theory $Y$ are researched time and again on different samples. Russ (2013) examined with managerial decision making, Kopelman, Prottas, and Falk (2010) considered working adults' behaviors for applying these theories, Russ (2013) examined the relationship of these theories with leader's communication apprehensions whereas Hommelhoff (2017) suggested that from the theory $X$ and theory $Y$ the appropriate theory is applied to maintain a trust with employees in service sector organizations. Unfortunately a chunk of studies have examined this issue in manufacturing and business organizations and also in prestigious sectors such as education has not been much focused upon (Parakhina et al., 2017). Furthermore, earlier researchers emphasized HR practices are not to blame in bringing employee behaviors but the way they are practiced and perceived (Ostroff \& Bowen, 2016). Similarly it is noted that human beings work for fulfillment of their needs and upon fulfillment they develop a tendency to work for the same organizations in the long run. The current study encompasses the examination in the higher education sector by considering a sample from the university staff. The following hypotheses are developed for statistical testing:

$H_{1 a}$ : There is a positive effect of applying theory $\mathrm{X}$ approach for motivation on retaining employees in private sector universities. 
$H_{1 b}$ : There is a positive effect of applying theory $\mathrm{Y}$ approach for motivation on retaining employees in private sector universities.

$H_{1 c}$ : There is a positive effect of applying Maslow's need theory approach for motivation on retaining employees in private sector universities.

\section{Employee Motivation (Theory X, Y and Maslow's Hierarchy) and Perfor- mance}

In the educational institutions adoption of practices based on enhancing employee's satisfaction has direct effect on the employees' outcome related to their performance. A greater satisfaction levels directs the energy in obtaining higher customer satisfaction by performing up to the mark. Over the past decades it is noticed that without the role of employees the organizations cannot perform well. A need is highlighted for managing employees in such a manner that adds value to the individual and organizational performance (Arslan \& Staub, 2013).

The earlier studies argued that it is not necessary that all types and styles of leadership reap favorable results when applied to organizational settings (Arslan \& Staub, 2013). This highlights the need to identify the right leadership approach for better individual and organizational outcomes.

It is reported that the higher turnover intentions and actual turnover is found linked with application of theory $\mathrm{X}$ and greater innovation and use of discretionary behaviors are found linked with theory Y (Arslan \& Staub, 2013). Employee work related outcomes are based on two major factors that are: the way they are dealt, and the fulfillment of their needs. The practices adopted by the leaders/ managers have a greater influence on the employees' work outcomes (Lam \& O'Higgins, 2012; Drescher, 2017). Stick and carrot approach is used by the managers for managing employee's performance effectively (Drescher, 2017). It is noted that satisfied emotional needs ensure enhanced employee productivity (Moore, Cruickshank, \& Haas, 2006).

At times the researchers argued that the use of stick approach and having a theory $X$ perspective had a long lasting and favorable effect on employees in terms of maintaining a discipline and meeting the time schedules (Davison \& Smothers, 2015); thus, making employees perform better. On the other hand, the researchers argued that being flexible and regarding employees for their efforts remains fruitful when it comes to making people productive (Sorensen \& Minahan, 2011); thus developing no consensus on the concrete findings regarding application of the leadership approaches to manage employee performance. Similarly the deficiency in needs fulfillment distracts the attention and energy of the employees from their work (Kumar \& Jauhari, 2016).

In the light of the above arguments the following hypothesis was developed;

$H_{2 a}$ : There is a positive effect of applying theory $\mathrm{X}$ approach for motivating employees on performance of employees in private sector universities. 
$H_{2 b}$ : There is a positive effect of applying theory $\mathrm{Y}$ approach for motivating employees on performance of employees in private sector universities.

$H_{2 c}$ : There is a positive effect of applying Maslow's need theory for motivating employees on performance of employees in private sector universities.

\section{Methodology}

The population for the study was comprised of the university employees including the teaching and non-teaching staff members of the private sector universities that are generally led by the single leader or a group of leaders. The styles adopted by them have concrete influences on the work related outcomes of the employees. The study used a sample of 219 respondents (teaching $=125$ and non-teaching $=94$ ). This distribution emerged as a result of willingness of respondents (male \& female/ teaching \& non-teaching) to participate in the survey. A well structured, closed ended questionnaire was distributed to record the responses. Theory $X$ and theory $Y$ questionnaire was adapted from Kopelman et al. (2010) whereas the statements regarding Maslow's hierarchy of needs were adapted from Taormina and Gao (2013). A likert scale representing values from 1 to 5 was used to gauge responses. Further the employee performance scale was adapted from the studies of Tangen (2005) for matching requirements of the study and finally the employee retention scale were adopted from (Cammann, Fichman, Jenkins, \& Klesh, 1979). The correlation and regression analysis was done using Statistical Package for Social Sciences to establish the relationships and to examine the cause and effect linkage of the constructs.

\section{Results}

The results of the current study are based on the 219 university staff members including the teaching and non-teaching members. Their average age was 41 years and their average work experience was 3.7 years. They worked on different academic and nonacademic positions. The respondents possessed good information about the practices being used by the university management for motivating them to work for the universities. In the selected sample 32 percent were female respondents and remaining were the male respondents.

The results of correlation analysis show that the "theory X approach" adopted by the private sector university leaders have negative relationship with employee retention $(\mathrm{r}=$ $-0.814, \mathrm{p}=0.000)$ and their performance $(\mathrm{r}=-0.957, \mathrm{p}=0.000)$. The correlation results also predicted that the "theory $\mathrm{Y}$ approach" has a positive relationship with employee retention $(\mathrm{r}=0.417, \mathrm{p}=0.000)$ and employee performance $(\mathrm{r}=0.428, \mathrm{p}=0.000)$. At the same time it is observed that the "Maslow's Needs theory approach" has a negative relationship with retention of employees $(r=-0.99, p=0.143)$ and performance of university employees 
$(\mathrm{r}=-0.105, \mathrm{p}=0.120)$. It is evident that both the relationships are non-significant statistically as well. The adoption of theory $X$ approach may lead to decreased needs fulfillment and thus decreases the chances of retaining the jobs and performance if harmed.

The results of correlation and regression analysis are reported below:

\begin{tabular}{|c|c|c|c|c|c|c|}
\hline & & TX & TY & MH & EP & ER \\
\hline \multirow[t]{3}{*}{ TX } & Pearson Correlation & 1 & $-.441^{* *}$ & 0.125 & $-.957^{* *}$ & $-.814^{* *}$ \\
\hline & Sig. (2-tailed) & & 0.000 & 0.065 & 0.000 & 0.000 \\
\hline & $\mathrm{N}$ & 219 & 219 & 219 & 219 & 219 \\
\hline \multirow[t]{3}{*}{ TY } & Pearson Correlation & $-.441^{* *}$ & 1 & -0.078 & $.428^{* *}$ & $.417^{* *}$ \\
\hline & Sig. (2-tailed) & 0.000 & & 0.249 & 0.000 & 0.000 \\
\hline & $\mathrm{N}$ & 219 & 219 & 219 & 219 & 219 \\
\hline \multirow[t]{3}{*}{ MH } & Pearson Correlation & 0.125 & -0.078 & 1 & -0.105 & -0.099 \\
\hline & Sig. (2-tailed) & 0.065 & 0.249 & & 0.12 & 0.143 \\
\hline & $\mathrm{N}$ & 219 & 219 & 219 & 219 & 219 \\
\hline \multirow[t]{3}{*}{ EP } & Pearson Correlation & $-.957^{* *}$ & $.428^{* *}$ & -0.105 & 1 & $.823^{* *}$ \\
\hline & Sig. (2-tailed) & 0.000 & 0.000 & 0.12 & & 0.000 \\
\hline & $\mathrm{N}$ & 219 & 219 & 219 & 219 & 219 \\
\hline \multirow[t]{3}{*}{ ER } & Pearson Correlation & $-.814^{* *}$ & $.417^{* *}$ & -0.099 & $.823^{* *}$ & 1 \\
\hline & Sig. (2-tailed) & 0.000 & 0.000 & 0.143 & 0.000 & \\
\hline & $\mathrm{N}$ & 219 & 219 & 219 & 219 & 219 \\
\hline
\end{tabular}

The results of regression analysis are divided into two sections. Once the regression analysis is done for the independent variables (theory $\mathrm{X}$ approach, theory $\mathrm{Y}$ approach and Maslow's needs theory approach) on the retention of employees; the effect of same independent variables is examined on the performance. The results are provided below;

\section{Theory X, Theory Y, Maslow's Needs theory and Employee Retention}

\begin{tabular}{|c|c|c|c|c|c|}
\hline Model & & $\mathbf{R}$ & R Square & Adjusted R Square & Std. Error of the Estimate \\
\hline dimension0 & 1 & $.816 a$ & 0.666 & 0.662 & 0.29514 \\
\hline
\end{tabular}

The coefficient of determination $\left(R^{2}\right)$ shows that the independent variables have 66.6 percent effect on the retention of employees and that is a stronger effect. For further analysis the value of F-statistic is observed and it showed a value of 143.133 with $p$ value equal to 0.000 showing the good model fitness.

The theory $\mathrm{X}$ perspective is shown to have a negative effect on the retention of employees $(\beta=-0.492, \mathrm{p}=0.000)$ and the theory $\mathrm{Y}$ perspective has a positive effect on the retention of employees $(\beta=0.188, \mathrm{p}=0.103)$. Further the Maslow's needs theory perspective has a very weak negative and non-significant effect on the retention of employees ( $\beta$ $=-0.002, \mathrm{p}=0.918)$. 
The beta values are shown in the subsequent table below;

\begin{tabular}{|c|c|c|c|c|c|c|}
\hline \multirow{2}{*}{\multicolumn{2}{|c|}{ Model }} & \multicolumn{2}{|c|}{ Unstandardized Coefficients } & \multirow{2}{*}{\multicolumn{3}{|c|}{$\begin{array}{l}\text { Standardized Coefficients } \\
\text { Beta }\end{array}$}} \\
\hline & & B & Std. Error & & & \\
\hline \multirow[t]{4}{*}{1} & (Constant) & 3.900 & 0.399 & & 9.773 & 0.000 \\
\hline & TX & -0.492 & 0.028 & -0.782 & -17.732 & 0.000 \\
\hline & TY & 0.188 & 0.114 & 0.072 & 1.639 & 0.103 \\
\hline & MH & -0.002 & 0.023 & 0.004 & 0.102 & 0.918 \\
\hline
\end{tabular}

This is also a clear predictor of the effects of theory $X$ perspective having negative impact on the retention and the Maslow's hierarchy having a negative effect means that the employees are not satisfied with their jobs and their needs are not being met in the private university thus, they are having intentions to leave their present job.

\section{Theory X, Theory Y, Maslow's Needs theory and Employee Performance}

The effect of independent variables (theory $X$, theory $Y$ and Maslow's needs theory) was examined on the performance of employees and the results are presented below;

Table 4

Model Summary

\begin{tabular}{|c|c|c|c|c|}
\hline Model & $\mathbf{R}$ & R Square & Adjusted R Square & Std. Error of the Estimate \\
\hline dimension 0 & $.957 a$ & 0.916 & 0.915 & 0.27288 \\
\hline
\end{tabular}

The value of $R$ square shows that the independent variables have $91.6 \%$ effect on the performance of employees. This meant that the more delicately the employees are dealt the better performance they will show. The value given to the employees is the predictor of their efforts and work well done. The F-statistic value is equal to 784.855 with a $p$ value is equal to 0.000 .

\begin{tabular}{|c|c|c|c|c|c|c|}
\hline \multirow{2}{*}{\multicolumn{2}{|c|}{ Model }} & \multicolumn{2}{|c|}{ Unstandardized Coefficients } & \multirow{2}{*}{\multicolumn{3}{|c|}{$\begin{array}{l}\text { Standardized Coefficients } \\
\text { Beta }\end{array}$}} \\
\hline & & B & Std. Error & & & \\
\hline \multirow[t]{4}{*}{1} & (Constant) & 6.206 & 0.369 & & 16.82 & 0.000 \\
\hline & TX & -1.109 & 0.026 & -0.956 & -43.259 & 0.000 \\
\hline & TY & 0.033 & 0.106 & 0.007 & 5.309 & 0.008 \\
\hline & MH & -0.015 & 0.021 & 0.014 & 0.727 & 0.468 \\
\hline
\end{tabular}

The beta values show the effect of each independent variable separately on the performance of employees, theory $\mathrm{X}(\beta=-1.109, \mathrm{p}=0.000)$, theory $\mathrm{Y}(\beta=0.033, \mathrm{p}=0.008)$, Maslow's Needs theory $(-0.015, \mathrm{p}=0.468)$. The situation is almost the same as with the retention of employees. The needs are not being fulfilled and the approach of theory $X$ is harming the performance of university employees. 
Having a look at the hypotheses which developed the hypothesis $1 \mathrm{~b}$ and hypothesis $2 \mathrm{~b}$ are accepted statistically showing a positive effect on employee retention and employee performance. Where the four hypotheses that are hypotheses $1 \mathrm{a}, 1 \mathrm{c}, 2 \mathrm{a}$, and 2c are rejected for not having significant values as well as the beta values are negative. This brought an interesting insight, with respect to private sector universities, to surface that are covered in the discussion section.

\section{Discussion and Conclusion}

The study was conducted by considering a sample of private sector university employees where the interaction of leaders and sub-ordinates is a frequent factor and moreover the policies are generally dependent upon the leader leading the university instead of having any stable policy structure. The moods and the practices adopted have direct effect on the employee work outcomes such as retention of jobs and their work related performance. The results of the current study are partially in line with the earlier studies conducted in the work settings (Pang \& Lu, 2018; Anitha, 2014).

Earlier studies revealed that the leaders/managers who give value to employees are more effective than others (Kim, 2016). The value provided to employees helps managers develop a trust factor among them and they collectively try their best to perform well and achieve the organizational goals. If the employees are perceived disrespectfully or treated with disrespect, they tend to develop a tendency of leaving the organization (Matongolo et al., 2018) that harms not only their individual performance but also the overall university performance (Parakhina et al., 2017).

It is necessary here to consider that what types of perspectives theory $X$ leaders hold towards their employees. They generally have the opinion that their employees have work avoiding attitude and they try to shirk work and hence need close supervision whereas this may not be the reality. The leaders generally hold opinions that their subordinates dislike work and try to waste time. Holding this opinion for all the employees may harm their inner feelings towards their organization and they get dissatisfied from their work and try to leave their workplaces (Dartey-Baah \& Ampofo, 2016), hypotheses $1 b$ and $2 b$.

On the other hand if the leaders value their employees and their work this may reap positive work outcomes and fulfill the individual work related goals and the organizational goals as a whole. It is an evident phenomenon that when the need of human beings are met in the best possible manner they try to keep their positions for contributed fulfillment of needs and try their best to be posing their pictures well in front of the bosses for better and brighter future and vice versa (Chen et al., 2012). Needs not fulfilled in an acceptable manner leads to hampered satisfaction from work and decreases productivity.

The results of the current study revealed that theory $X$ approach and not fulfillment of the needs are harmful to the retention and performance of employees. It means that the majority of the leaders/managers in private sector universities deal with their subordinates by ignoring their respect and by not providing them with resources and eventually harming their retention and performance. There can be other reasons behind the 
employees having weak retention intentions. The university employees, especially the faculty members are more educated and want to be treated with respect and honor. If they are not treated with respect they tend to leave the universities upon not fulfillment of their needs. The rejection of hypotheses $1 c$ and $2 c$ seemingly took place due to these reasons.

The results of the study helped in concluding that theory $X$ approach adopted by the university management (leaders) has a negative impact on the retention and performance of employees; therefore, employees feel disgraced and do not want to retain their jobs and perform at lower levels but theory $\mathrm{Y}$ approach adopted by the leaders in the same university gives confidence to the employees and help develop a sense of trust that boosts their morale and the employees develop a tendency to remain in their same jobs and perform. The Maslow's needs theory applied reaped negative results, this might be due to the fact that the leaders are mostly applying theory $X$ approach for managing the work activities and these practices are negatively perceived by the employees.

\section{Suggestions}

The leaders adopting theory $X$ perspective may consider using this approach at an appropriate time. It is more likely that having the same perspective regarding all employees may not reap fruitful results for the private sector university as is observed in the current study. Adoption of the same perspective for all and considering all employees as dull and not contributors to the organization may harm their self-esteem and they become dissatisfied from their jobs and bosses.

The leaders should consider applying the theory Y approach as the results show a positive impact on retention of jobs and performance. The managers who have the capability to retain the employees for longer may also manage their performance by following better perimeters. The relationship built with the university and the leaders leading it boosts affective commitment among employees and they produce positive results.

A perception of Maslow's needs theory also seems to have negative impacts. The leaders should consider providing support to their subordinates and provide them guidance and resources so that the employees feel comfortable at workplace and their work related needs should be met for better performance instead of always looking them as work shirkers.

\section{Limitations and Future Directions}

A limited sample size of 219 university members may not be sufficient in drawing the meaningful results. Therefore, it is recommended for future research studies to select a larger sample size for through insights. Similarly the private sector universities are only considered for the study, it will be more interesting to select the public sector universities as well to investigate the same relationships in a diverse sample. 


\section{References}

Alferaih, A., Sarwar, S., \& Eid, A. (2018). Talent turnover and retention research: The case of tourism sector organisations in Saudi Arabia. In Evidence-based HRM: A Global Forum for Empirical Scholarship. doi: 10.1108/EBHRM-06-2017-0035

Anitha, J. (2014). Determinants of employee engagement and their impact on employee performance. International Journal of Productivity and Performance Management, 63(3), 308-323.

Arslan, A., \& Staub, S. (2013). Theory X and Theory Y type leadership behavior and its impact on organizational performance: Small business owners in the ssishane lighting and chandelier district. Procedia-social and Behavioral Sciences, 75, 102-111.

Cammann, C., Fichman, M., Jenkins, D., \& Klesh, J. (1979). The michigan organizational assessment questionnaire. Unpublished manuscript, University of Michigan, Ann Arbor.

Chen, X.-H., Zhao, K., Liu, X., \& Dash Wu, D. (2012). Improving employees' job satisfaction and innovation performance using conflict management. International Journal of Conflict Management, 23(2), 151-172.

Dartey-Baah, K., \& Ampofo, E. (2016). "Carrot and stick" leadership style: Can it predict employees job satisfaction in a contemporary business organisation? African Journal of Economic and Management Studies, 7(3), 328-345.

Das, B. L., \& Baruah, M. (2013). Employee retention: A review of literature. Journal of Business and Management, 14(2), 8-16.

Davison, H. K., \& Smothers, J. (2015). How Theory X style of management arose from a fundamental attribution error. Journal of Management History, 21(2), 210-231.

Dechawatanapaisal, D. (2018). Employee retention: The effects of internal branding and brand attitudes in sales organizations. Personnel Review, 47(3), 675-693.

Drescher, G. (2017). Delegation outcomes: Perceptions of leaders and follower's satisfaction. Journal of Managerial Psychology, 32(1), 2-15.

Fatehi, K., Veliyath, R., \& Derakhshan, F. (2008). Emergent realities of global competition: The changing demands on managers and governments. International Journal of Commerce and Management, 18(1), 77-92.

Gürbüz, S., Şahin, F., \& Köksal, O. (2014). Revisiting of Theory X and Y: A multilevel analysis of the effects of leaders' managerial assumptions on followers' attitudes. Management Decision, 52(10), 1888-1906.

Gwavuya, F. (2011). Leadership influences on turnover intentions of academic staff in tertiary institutions in Zimbabwe. Academic Leadership: The Online Journal, 9(1), 115.

Gyensare, M. A., Anku-Tsede, O., Sanda, M.-A., \& Okpoti, C. A. (2016). Transformational leadership and employee turnover intention: The mediating role of affective commitment. World Journal of Entrepreneurship, Management and Sustainable Development, 12(3), 243-266.

Hommelhoff, S. (2017). Implicit managerial theories about followers and customers. Journal of Service Theory and Practice, 27(1), 47-68. 
Kim, S. (2016). Factors affecting employment retention among older workers in South Korea. Working with Older People, 20(1), 14-22.

Kopelman, R. E., Prottas, D. J., \& Falk, D. W. (2010). Construct validation of a Theory X/Y behavior scale. Leadership E Organization Development Journal, 31(2), 120-135.

Kumar, M., \& Jauhari, H. (2016). Satisfaction of learning, performance, and relatedness needs at work and employees organizational identification. International Journal of Productivity and Performance Management, 65(6), 760-772.

Lam, C. S., \& O'Higgins, E. R. (2012). Enhancing employee outcomes: The interrelated influences of managers' emotional intelligence and leadership style. Leadership and Organization Development Journal, 33(2), 149-174.

Madariaga, R., Oller, R., \& Martori, J. C. (2018). Discrete choice and survival models in employee turnover analysis. Employee Relations, 40(2), 381-395.

Matongolo, A., Kasekende, F., \& Mafabi, S. (2018). Employer branding and talent retention: Perceptions of employees in higher education institutions in Uganda. Industrial and Commercial Training.

Moore, K., Cruickshank, M., \& Haas, M. (2006). Job satisfaction in occupational therapy: A qualitative investigation in urban Australia. Australian Occupational Therapy Journal, 53(1), 18-26.

Ng'ethe, J. M., Namusonge, G., \& Iravo, M. A. (2012). Influence of leadership style on academic staff retention in public universities in Kenya. International Journal of Business and Social Science, 3(21), 297-302.

Ostroff, C., \& Bowen, D. E. (2016). Reflections on the 2014 decade award: Is there strength in the construct of hr system strength? Academy of Management Review, 41(2), 196214.

Pang, K., \& Lu, C.-S. (2018). Organizational motivation, employee job satisfaction and organizational performance: An empirical study of container shipping companies in taiwan. Maritime Business Review. doi: 10.1108/MABR-03-2018-0007

Parakhina, V., Godina, O., Boris, O., \& Ushvitsky, L. (2017). Strategic management in universities as a factor of their global competitiveness. International Journal of Educational Management, 31(1), 62-75.

Rao, M. (2017). Employees first, customers second and shareholders third? Towards a modern HR philosophy. Human Resource Management International Digest, 25(6), 6-9.

Russ, T. L. (2013). The relationship between Theory X/Y: Assumptions and communication apprehension. Leadership E Organization Development Journal, 34(3), 238-249.

Sorensen, P. F., \& Minahan, M. (2011). Mcgregor's legacy: The evolution and current application of Theory Y management. Journal of Management History, 17(2), 178-192.

Tangen, S. (2005). Demystifying productivity and performance. International Journal of Productivity and Performance Management, 54(1), 34-46.

Taormina, R. J., \& Gao, J. H. (2013). Maslow and the motivation hierarchy: Measuring satisfaction of the needs. The American Journal of Psychology, 126(2), 155-177.

Umer, A., Khalil, A. A., \& Shirwani, A. (2016). Impact of HR policies on employee motivation in private schools of Karachi, Pakistan. Journal of Education E Social Sciences, 4(1), 51-69. 